\title{
EPIGAEIC ANTS IN A FOREST REMNANT IN THE STATE OF ACRE, BRAZIL AND NEW RECORDS FOR THE STATE
}

\author{
Rodrigo Souza Santos ${ }^{1}$; Jacques Hubert Charles Delabie ${ }^{2}$
}

\begin{abstract}
${ }^{1}$ Empresa Brasileira de Pesquisa Agropecuária - Embrapa Acre. E-mail: rodrigo.s.santos@embrapa.br
${ }^{2}$ Centro de Pesquisas do Cacau (CEPLAC-CEPEC) and Universidade Estadual de Santa Cruz (UESC-DCAA). E-mail: jacques.delabie@gmail.com
\end{abstract}

\section{ABSTRACT}

Ants are considered an important group of invertebrates in terrestrial ecosystems, where they participate in important ecological processes between animals and plants, and they are considered good indicators of environmental impacts as well. Although the diversity of ants in the Amazon biome is already relatively well known, the ant fauna in the state of Acre, Brazil is still poorly known. The aim of this study was to carry out a survey of ants in a forest remnant located in the municipality of Plácido de Castro, Acre, using pitfall traps. Thirty-six species of ants were collected from six subfamilies and 18 genera. From the species confirmed, 11 (Cephalotes serraticeps, Gnamptogenys moelleri, Gnamptogenys triangularis, Neoponera apicalis, Neoponera commutata, Neoponera verenae, Mayaponera constricta, Megalomyrmex emeryi, Pachycondyla impressa, Pheidole araneoides and Odontomachus caelatus) are first records for Acre state, increasing our knowledge of the epigaeic ants that occur in this region of the Amazon.

Keywords: Bioindicators, diversity, Formicidae, soil fauna

\section{FORMIGAS EPIGEIAS EM REMANESCENTE FLORESTAL NO ESTADO DO ACRE E NOVOS REGISTROS PARA O ESTADO}

\section{RESUMO}

As formigas são consideradas um significante grupo de invertebrados nos ecossistemas terrestres, participando de importantes processos ecológicos entre animais e plantas, além de serem consideradas como bons indicadores de impactos ambientais. Apesar de a diversidade de formigas no bioma Amazônico já ser relativamente bem conhecida, a fauna de formigas do estado do Acre ainda é incipientemente estudada. O objetivo deste estudo foi realizar um levantamento de formigas em um remanescente florestal localizado no município de Plácido de Castro - Acre, utilizando armadilhas do 
tipo "pitfall trap". Foram coletadas 36 espécies de formigas, pertencentes a seis subfamílias e 18 gêneros. Das espécies confirmadas, 11 (Cephalotes serraticeps, Gnamptogenys moelleri, Gnamptogenys triangularis, Neoponera apicalis, Neoponera commutata, Neoponera verenae, Mayaponera constricta, Megalomyrmex emeryi, Pachycondyla impressa, Pheidole araneoides e Odontomachus caelatus) representam primeiros registros para o estado do Acre, aumentando o conhecimento acerca das formigas epigeias que ocorrem nesta região da Amazônia.

Palavras-chave: Bioindicadores, diversidade, Formicidae, fauna do solo

\section{INTRODUCTION}

According to Wink et al. (2005), the environmental balance of soils can be measured by observing the population characteristics of groups of organisms, and the diversity of soil insects is a good indicator of the level of environmental quality, based on which interventions can be determined to maintain, recover or restore the health of the environment aiming at the ecological sustainability of ecosystems. Insects are generally considered to be good bioindicators because they respond quickly to environmental stress and have short intervals between generations, and most are easily sampled and identified (PECK et al., 1998). As an example of bioindicator insects, the ants (Hymenoptera) stand out because they have the above qualities and respond rapidly to anthropic alterations, such as forest fragmentation (MAJER, 1983; OLIVEIRA et al., 2014).

Ants constitute the largest group of social insects of the order Hymenoptera, and the family Formicidae stands out because all species are truly social (FERNÁNDEZ, 2003). These insects are dominant in most terrestrial ecosystems and widely distributed geographically, being absent only in the polar regions and aquatic environments (WILSON, 1987; HÖLLDOWLER \& WILSON, 1990). They are considered one of the most important groups of invertebrates of terrestrial environments due to several attributes, namely high diversity and numerical and biomass predominance; they are present throughout the year and exert important ecological functions, including interactions with organisms of all trophic levels (ALONSO \& AGOSTI, 2000).

Studies involving inventories and modifications of the ant community after environmental disturbances, as well as the identification of bioindicator species, have been conducted with standardized methods that use the edaphic myrmecofauna as the basis of the research (KING et al., 1998; BIEBER et al., 2005; VASCONCELOS et al., 2008). Particularly, the sampling of epigeic ant assemblages in biodiversity and environmental impact studies is highly recommended in ecological evaluation due to its 
relative stability, diversity and sensitivity to microclimates and also the efficiency of methods for the collection of ants (ALONSO \& AGOSTI, 2000).

Among the various sampling methods used in faunistic surveys of ants, the following stand out: manual collection, collection using baits, Winkler extractors and pitfall-type traps. The traps are considered to be efficient, inexpensive and easy to install, and they can remain in place for extended periods (BESTELMEYER et al., 2000; AQUINO et al., 2006). In addition, the use of pitfall traps in transects, set up between and within habitats, is an efficient way of evaluating the spatial and seasonal distribution of soil insects (BEDFORD \& USHER, 1994). The use of traps arranged in transects allows the measure of population aggregation and determination of distribution patterns, providing an understanding of the movement of individuals and populations between environments in response to changes provoked by humans in the environment.

The ant fauna of the state of Acre in Brazil is still poorly known, and only studies by Oliveira et al. (2009), Miranda et al. (2012) and Miranda et al. (2013) systematically analyzed this animal group in this region of the Brazilian Amazon. The aim of this study was to evaluate the structure of the epigaeic ant assemblage in a forest remnant located in Acre to increase our knowledge of the state's myrmecological fauna.

\section{MATERIAL AND METHODS}

The study was carried out from August 2014 to August 2015, in a forest remnant of approximately 8 ha, located at Fazenda Amoty in the municipality of Plácido de Castro, Acre state (10²0’19.3”S, $67^{\circ} 29^{\prime} 06.2$ 'W; altitude of $201 \mathrm{~m}$ ). This forest remnant is bordered by capoeira fields and pastures.

Sampling was carried out by a passive capture method, using pitfall trap (ground-type traps) (BESTELMEYER et al., 2000; OLIVEIRA et al., 2009). These traps consisted of a transparent, $500 \mathrm{~mL}$ acrylic cup containing solution $1 \%$ formaldehyde and a few drops of neutral detergent. The pitfall traps were installed at $10 \mathrm{~m}$ intervals and arranged in two parallel transects (11 traps per transect), five meters apart, from the edge to the interior of the forest remnant. The samples were performed biweekly, and the traps were collected and replaced with new ones, totaling 22 series of samples during the study period.

The collected material was transported to the Laboratory of Entomology of Embrapa Acre, Rio Branco - Acre, where it was sorted. The contents of each pitfall trap were sieved, the ants being separated from the rest of the material. The captured specimens were morphotyped under a stereomicroscope and fixed in $70 \%$ alcohol. The ants were then sent to the Laboratory of Mirmecology of the Cacao Research 
Center (CEPLAC/CEPEC) in Itabuna, Bahia state, where they were identified to the lowest possible taxonomic level and deposited in the reference collection.

The classification used included recent changes in the levels of subfamilies and tribes according to Brady et al. (2014) and Ward et al. (2015).

\section{RESULTS AND DISCUSSION}

A total of 36 species of ants were collected. They were distributed in six subfamilies: Myrmicinae (13 species $-36.1 \%$ of the total species collected), Ponerinae $(10-27.8 \%)$, Ectatomminae $(4-11.1 \%)$, Formicinae $(4-11.1 \%)$, Dorylinae $(3-8.3 \%)$, and Dolichoderinae $(2-5.6 \%)$. The genera and their respective numbers of species were: Pheidole (4 species), Camponotus (4), Neoponera (3), Odontomachus (3), Pachycondyla (3), Gnamptogenys (3), Sericomyrmex (2), Eciton (2), Dolichoderus (2), Crematogaster (2), Atta (1), Ectatomma (1), Labidus (1), Mycocepurus (1), Wasmannia (1), Megalomyrmex (1), Mayaponera (1), and Cephalotes (1) (Table 1).

In relation to the functional groups presented by Brandão et al. (2012), the remnant area showed the following data: a) specimens belonging to the groups of genera including generalist and/or arboreal dominant species (Camponotus, Crematogaster, Pheidole, Megalomyrmex, and Wasmannia), (12 species); b) generalist predators (Ectatomma, Gnamptogenys, Mayaponera, Neoponera, Odontomachus, and Pachycondyla) (14 species), c) omnívores (Dolichoderus) (2 species), d) fungus cultivators on fresh or died plant material (Atta, Sericomyrmex and Mycocepurus) (4 species), e) army ants (Eciton and Labidus) (3 species) and e) arboreal ants that feed, at least in part, on pollen (Cephalotes) (1 species).

In this survey, species belonging to the subfamilies Myrmicinae and Ponerinae and of the genera Camponotus and Pheidole predominated (Table 1). Other studies carried out in forest areas in Acre also pointed out the predominance of Myrmicinae and Ponerinae, reinforcing the prevalence of these subfamilies in the forests of this state (OLIVEIRA et al., 2009; MIRANDA et al., 2013).

The subfamily Myrmicinae is considered to be the most abundant in the Neotropical region, due to the fact that the species easily adapt to various ecological niches and environmental conditions, making it feasible to control resources through efficient recruitment mechanisms (FOWLER et al., 1991; ANDERSEN, 1992). The subfamily Ponerinae includes species that have a preference for forests in the intertropical regions. They are generalists and can consume honeydew, fruit pulp, seeds and animal carcasses. Predator species play a regulatory role in the populations of many other arthropod groups and can act as indicators of their diversity (BACCARO et al., 2015). 
The genera Camponotus and Pheidole are the most common and diverse among all ants, especially in the Neotropical region (HÖLLDOBLER \& WILSON, 1991; WILSON, 2003), a finding that is supported by most of the studies carried out in Brazil, independently of the method used and study area (ANDRADE et al., 2007; ROSADO et al., 2014). The higher representativeness of these groups is due to the occurrence of many aggressive and dominant, generalist and/or omnivorous species (SILVESTRE et al., 2003). Pheidole is considered a hyperdiverse genus, widely distributed and composed of generalist species. This genus is known for its mass recruitment system, which enables it to dominate food resources and effectively exclude its competitors (FOWLER, 1993). Camponotus is made up of generalist species with terrestrial and arboreal habits, with high capacity to occupy new environments, due to its adaptability and flexibility of its diet (RAMOS et al., 2003; DELABIE et al., 2006).

Leaf-cutting ants (Myrmicinae) create clearings inside the forest, contributing to the sucession of plant species in the forest environment (GARRETTSON et al., 1998), predator species (Ponerinae) attack herbivorous insects (WIRTH \& LEAL, 2001). In addition, many ant species act as secondary seed dispersers (ROBERTS \& HEITHAUS, 1986).

Species of the genus Pachycondyla are commonly collected in a few disturbed environments. Species of this genus and of other neighbor genera of the Ponerini tribe have also been observed carrying seeds from the primary forest to pastures.

Among the Dorylinae, also known as "army ants", two genera (Eciton and Labidus) were collected from the five genera described in the literature. Ants of these genera are carnivorous and aggressive, forage in groups and migrate frequently, affecting the structure and composition of the communities through which they pass (DELABIE et al., 2000).

The present study added 11 species to the list of Formicidae of the state of Acre (Cephalotes serraticeps (Fr. Smith), Gnamptogenys moelleri (Forel), Gnamptogenys triangularis (Mayr), Neoponera apicalis (Latreille), Neoponera commutata (Roger), Neoponera verenae Forel, Mayaponera constricta (Mayr), Megalomyrmex emeryi Forel, Pachycondyla impressa (Roger), Pheidole araneoides Wilson, and Odontomachus caelatus Brown). The number of new records obtained in this survey demonstrates that information about the myrmecological fauna of Acre is still lacking. Thus, there is a need for further studies using different capture methods and in a greater diversity of environments, which would contribute to a more comprehensive view of the epigaeic ant fauna of this state. 
Table 1. Formicidae captured with pitfall traps in a forest remnant in the municipality of Plácido de Castro, Acre state from August 2014 to August 2015.

\begin{tabular}{|c|c|c|c|}
\hline Subfamily & Tribe & Species & Record \\
\hline \multirow{13}{*}{ Myrmicinae } & \multirow{10}{*}{ Attini } & Sericomyrmex sp.1 & \\
\hline & & Sericomyrmex sp. 2 & \\
\hline & & Atta cephalotes (L.) & 1 \\
\hline & & Mycocepurus goeldii (Forel) & 1 and 2 \\
\hline & & Pheidole sp. 1 & \\
\hline & & Pheidole sp. 2 & \\
\hline & & Pheidole araneoides Wilson & \\
\hline & & Pheidole pr. terribilis & \\
\hline & & Wasmannia auropunctata (Roger) & 1,2 and 3 \\
\hline & & Cephalotes serraticeps (Fr. Smith) & \\
\hline & \multirow{2}{*}{ Crematogastrini } & Crematogaster tenuicula Forel & 1,2 and 3 \\
\hline & & Crematogaster nigropilosa Mayr & $1 \mathrm{e} 2$ \\
\hline & Solenopsidini & Megalomyrmex emeryi Forel & \\
\hline \multirow{10}{*}{ Ponerinae } & \multirow{10}{*}{ Ponerini } & Odontomachus haematodus (L.) & 1,2 and 3 \\
\hline & & Odontomachus bauri Emery & 1,2 and 3 \\
\hline & & Odontomachus caelatus Brown & \\
\hline & & Pachycondyla harpax (Fabricius) & 1 and 2 \\
\hline & & Pachycondyla crassinoda (Latreille) & 1,2 and 3 \\
\hline & & Pachycondyla impressa (Roger) & \\
\hline & & Neoponera verenae Forel & \\
\hline & & Neoponera apicalis (Latreille) & \\
\hline & & Neoponera commutata (Roger) & \\
\hline & & Mayaponera constricta (Mayr) & \\
\hline \multirow{4}{*}{ Formicinae } & \multirow{4}{*}{ Camponotini } & Camponotus (Tanaemyrmex) sp. & \\
\hline & & Camponotus fastigatus (Roger) & 1,2 and 3 \\
\hline & & Camponotus atriceps (Fr. Smith) & 1,2 and 3 \\
\hline & & Camponotus cacicus Emery & 1 and 2 \\
\hline \multirow{4}{*}{ Ectatomminae } & \multirow{4}{*}{ Ectatommini } & Ectatomma suzanae Almeida & 1 and 2 \\
\hline & & Gnamptogenys sulcata (Fr. Smith) & 1,2 and 3 \\
\hline & & Gnamptogenys moelleri (Forel) & \\
\hline & & Gnamptogenys triangularis (Mayr) & \\
\hline \multirow{3}{*}{ Dorylinae } & \multirow{3}{*}{ Ecitonini } & Eciton burchellii (Westwood) & 1 and 2 \\
\hline & & Eciton hamatum (Fabricius) & 1 and 2 \\
\hline & & Labidus spininodis (Emery) & 1 and 2 \\
\hline \multirow{2}{*}{ Dolichoderinae } & \multirow{2}{*}{ Dolichoderini } & Dolichoderus bidens (L.) & 1 and 2 \\
\hline & & Dolichoderus attelaboides (Fabricius) & 1 and 2 \\
\hline
\end{tabular}

Legend: 1 = Oliveira et al. (2009); 2 = Miranda et al. (2012) and 3 = Miranda et al. (2013)

\section{CONCLUSION}

From the 36 species collected in this survey, $30.5 \%$ represented new records for the state of Acre, increasing our knowledge of the epigaeic ant fauna in this western region of the Amazon. 


\section{ACKNOWLEDGEMENTS}

To teacher MSc. Luciana Maira de Sales Pereira (Instituto Federal do Acre - IFAC, Rio Branco, Acre state, Brazil) for review of the manuscript and the biologists Conceição Paula Bandeira Rufino, Clemeson Silva de Souza, Darlan Santiago Aiache and Marlene Gomes da Silva for the aid with the samples. JHCD acknowledges his research grant from CNPq.

\section{REFERENCES}

ALONSO, L.E.; AGOSTI, D. 2000. Biodiversity studies, monitoring and ants: an overview. In: AGOSTI, D.; MAJER, J.D.; ALONSO, L.E.; SCHULTZ, T.R. (Eds.). Ants: Standard methods for measuring and monitoring biodiversity. Washington: Smithsonian Institution Press. 280p.

ANDERSEN, R.N. 1992. Regulation of momentary diversity by dominant species in exceptionally rich ant community structure of the Australian seasonal tropics. The American Naturalist, Chicago, v.140, n.3, p.401-420.

ANDRADE, T.; MARQUES, G.D.V.; DEL-CLARO, K. 2007. Diversity of ground dwelling ants in Cerrado: an analysis of temporal variations and distinctive physiognomies of vegetation (Hymenoptera: Formicidae). Sociobiology, Feira de Santana, v.50, n.1, p.1-14.

AQUINO, A.M.; AGUIAR-MENEZES, E.L.; QUEIROZ, J.M. 2006. Recomendações para coleta de artrópodes terrestres por armadilhas de queda ("pitfall-traps"). Embrapa, Circular Técnica 30. $8 \mathrm{p}$.

BACCARO, F.B.; FEITOSA, R, M, FERNÁNDEZ, F.; FERNANDES, I.O.; IZZO, T.J.; SOUZA, J.L.P.; SOLAR, R. 2015. Guia para os gêneros de formigas do Brasil. Manaus: Editora INPA. 388p.

BEDFORD, S.E.; USHER, M.B. 1994. Distribution of arthropod species across the margins of farm woodlands. Agriculture, Ecosystem \& Environment, Amsterdam, v.48, n.3, p.295-305.

BESTELMEYER, B.T.; AGOSTI, D.; ALONSO, L.E.; BRANDÃO, C.R.F.; BROWN Jr., W, L, DELABIE, J.H.C.; SILVESTRE, R. 2000. Field techniques for the study of ground-living ants: an overview, description, and evaluation. In: AGOSTI, D.; MAJER, J.D.; ALONSO, L, E.; SCHULTZ, T.R. (Eds.). Ants: Standard Methods for measuring and monitoring biodiversity. Washington: Smithsonian Institution. 280p.

BIEBER, A.G.D.; DARRAULT, O.P.G.; RAMOS, C.C.; MELO, K.K.; LEAL, I.R. 2005. Formigas. In: PÔRTO, K.C.; ALMEIDA-CORTEZ, J.S.; TABARELLI, M. (Orgs.). Diversidade biológica e conservação da floresta Atlântica ao Norte do Rio São Francisco. Brasília: Ministério do Meio Ambiente. 363p.

BRADY, S.G.; FISHER, B.L.; SCHULTZ, T.R.; WARD, P.S. 2014. The rise of army ants and their relatives: diversification of specialized predatory doryline ants. BMC Evolutionary Biology, London, v.14, n.93. p.1-14.

BRANDÃO, C.R.F.; SILVA, R.R.; DELABIE, J.H.C. 2012. Neotropical ants (Hymenoptera) functional groups: nutritional and applied implications. In: PANIZZI, A.R.; PARRA, J.R.P. (Eds.). Insect bioecology and nutrition for integrated pest management. Boca Raton: CRS Press. 750p.

DELABIE, J.H.C.; AGOSTI, D.; NASCIMENTO, I.C. 2000. Litter and communities of the Brazilian Atlantic rain forest region. In: AGOSTI, D.; MAJER, J.D.; ALONSO, L.E.; SCHULTZ, T.R. (Eds.). 
Ants: Standard methods for measuring and monitoring biodiversity. Washington: Smithsonian Institution Press. 280p.

DELABIE, J.H.C.; PAIM, V.R.L.D.; NASCIMENTO, I.C.; CAMPIOLO, S.; MARIANO, C.D.S.F. 2006. As formigas como indicadores biológicos do impacto humano em manguezais da costa sudeste da Bahia. Neotropical Entomology, Londrina, v.35, n.5, p.602-615.

FERNÁNDEZ, F. 2003. Subfamília Formicinae. In: FERNÁNDEZ, F. (Ed.). Introducción a las hormigas de la región Neotropical. Bogotá: Instituto de Investigación de Recursos Biológicos Alexander Von Humboldt. 398p.

FOWLER, H.G. 1993. Relative representation of Pheidole (Hymenoptera: Formicidae) in local ground ant assemblages of the Americas. Anales de Biologia, Roma, v.19, n.8, p.29-37.

FOWLER, H.G.; FORTI, L.C.; BRANDÃO, C.R.F.; DELABIE, J.H.C.; VASCONCELOS, H.L. 1991. Ecologia nutricional de formigas. In: PANIZZI, A.R.; PARRA, J.R.P. (Eds.). Ecologia nutricional de insetos e suas implicações no manejo integrado de pragas. São Paulo: Editora Manole Ltda. 360p.

GARRETTSON, M.; STETZEL, J.F.; HALPERN, B.S.; HEARN, D.J.; LUCEY, B.T.; McKONE, M.J. 1990. Diversity and abundance of understorey plants on active and abandoned nests of leaf-cutting ants (Atta cephalotes) in Costa Rica rain forest. Journal of Tropical Ecology, Local? v.14, n.1, p.17-26.

HÖLLDOBLER, B.; WILSON, E.O. 1990. The ants. Cambridge: Belknap. 732p.

KING, J.A.R.; ANDERSEN, A.N.; CUTTER, A.D. 1998. Ants as bioindicators of habitat disturbance: validation of the functional group model for Australia's humid tropics. Biodiversity \& Conservation, Dordrecht, v.7, n.12, p.1627-1638.

MAJER, J.D. 1983. Ants: bio-indicators of minesite rehabilitation, land-use, and land conservation. Environmental Management, New York, v.7, n.4, p.375-383.

MIRANDA, P.N.; OLIVEIRA, M.A.; BACCARO, F.B.; MORATO, E.F.; DELABIE, J.H.C. 2012. Check list of ground-dwelling ants (Hymenoptera: Formicidae) of the eastern Acre, Amazon, Brazil. Check List, São Paulo, v.8, n.4, p.722-730.

MIRANDA, P.N.; MORATO, E.F.; OLIVEIRA, M.A.; DELABIE, J.H.C. 2013. A riqueza e composição de formigas como indicadores dos efeitos do manejo florestal de baixo impacto em floresta tropical no estado do Acre. Revista Árvore, Viçosa, v.37, n.1, p.163-173.

OLIVEIRA, M.A.; GOMES, C.F.F.; PIRES, E.M.; MARINHO, C.G.S.; DELLA LUCIA, T.M.C. 2014. Bioindicadores ambientais: insetos como um instrumento desta avaliação. Revista Ceres, Viçosa, v.61, p.800-807.

OLIVEIRA, M.A.; DELLA LUCIA, T.M.C.; MARINHO, C.G.S.; DELABIE, J.H.C.; MORATO, E.F. 2009. Ant (Hymenoptera: Formicidae) diversity in an area of the Amazon forest in Acre, Brazil. Sociobiology, Feira de Santana, v.54, n.1, p.1-25

PECK, S.L.; McQUAID, B.; CAMPBEL, C.L. 1998. Using ant species (Hymenoptera: Formicidae) as a biological indicator of agroecosystem condition. Environmental Entomology, Washington, v.27, n.5, p.1102-1110.

RAMOS, L.S.; MARINHO, C.G.S.; FILHO, R.Z.B.; DELABIE, J.H.C.; LACAU, S.; SANTOS, M.D.F.S.D.; NASCIMENOT, I.C.D. 2003. Comunidades de formigas (Hymenoptera: Formicidae) de serapilheira em áreas de cerrado "stricto sensu" em Minas Gerais. Lundiana, Belo Horizonte, v.4, n.2, p.95-102.

ROBERTS, J.T.; HEITHAUS, E.R. 1986. Ants rearrange the vertebrate-generated seed shadow of a Neotropical fig tree. Ecology, Washington, v.67, n.4, p.1046-1051. 
ROCHA, W.O.; DORVAL, A.; PERES FILHO, O.; VAEZ, C.A.; RIBEIRO, E.S. 2015. Formigas (Hymenoptera: Formicidae) bioindicadoras de degradação ambiental em Poxoréu, Mato Grosso, Brasil. Floresta e Ambiente, Seropédica, v.22, n.1, p.88-98.

ROSADO, J.L.O.; BECKMANN, G.H.; PATRICIO, R.S.; HARTER-MARQUES, B. 2014. Estrutura da assembleia de formigas (Hymenoptera: Formicidae) epigéicas em áreas reabilitadas após mineração de carvão a céu aberto no Sul de Santa Catarina, Brasil. Revista Tecnologia e Ambiente, Criciúma, v.21, p.207-227.

SILVESTRE, R.C.; BRANDÃO, R.F.; SILVA, R.R. 2003. Grupos funcionales de hormigas: el caso de los gremios del Cerrado. In: FERNÁNDEZ, F. (Ed.). Introducción a las hormigas de la región Neotropical. Bogotá: Instituto de Investigación de Recursos Biológicos Alexander Von Humboldt. 398p.

VASCONCELOS, H.L.; LEITE, M.F.; VILHENA, J.M.S.; LIMA, A.P.; MAGNUSSON, W.E. 2008. Ant diversity in an Amazonian savanna: relationship with vegetation structure, disturbance by fire, and dominant ants. Austral Ecology, Malden, v.33, p.221-231.

WARD, P.S.; BRADY, S.G.; FISHER, B.L.; SCHULTZ, T.R. 2015. The evolution of myrmicine ants: phylogeny and biogeography of a hyperdiverse ant clade (Hymenoptera: Formicidae). Systematic Entomology, Medford, v.40, n.1, p.61-81.

WILSON, E.O. 1987. Causes of ecological success: the case of the ants. Journal of Animal Ecology, London, v.56, n.1, p.1-9.

WILSON, E.O. 2003. Pheidole in the New World, a dominant, hyperdivese ant genus. Harvard University Press, Cambridge, Massachusetts, 794p.

WINK, C.; GUEDES, J.V.C.; FAGUNDES, C.K.; ROVEDDER, A.P. 2001. Insetos edáficos como indicadores da qualidade ambiental. Revista de Ciências Agroveterinárias, Lages, v.4, n.1, p.6071.

WIRTH, R.; LEAL, I.R. 2001, Does rainfall affect temporal variability of ant protection in Passiflora coccinea? Écoscience, Québec, v.8, n.4, p.450-453. 